\title{
Is Garnishee Proceeding Feasible on Islamic Banking Deposits and Investment Accounts in Malaysia?
}

\author{
Apnizan Abdullah*
}

\section{Introduction}

It is common in loans or debts recovery action that once a creditor obtains a judgment from the court of law against his debtor, he will eventually proceed to enforce it. Fundamentally, there are several methods of enforcement of the judgment available to the judgment creditor, inter alia writ of execution which includes writ of seizure and sale, writ of possession and writ of delivery, judgment debtor summons, stop orders, appointment of receiver and committal. Another prevailing mode of the enforcement of judgment in the market is garnishee proceeding. Procedurally, a garnishee proceeding is initiated by a judgment creditor by way of applying to the court for an order to be issued on a person who is indebted to the judgment debtor (a garnishee) to satisfy the amount judgment sum or a sum of an order of payment issued by the court against the judgment debtor. The very reason why a garnishee proceeding can be brought against a garnishee is that there is a debtor-creditor relationship between the garnishee and the judgment debtor. This procedure is very typical in the conventional banking sector since the relation between the banks and their customers is a debtorcreditor relationship. In the conventional banking practice, every deposit placed by a customer in either current, saving or investment accounts at his bank is constituted as a loan to the bank. However, this is not the only relationship that occurs between a customer of an Islamic financial institution (IFI) and his bank. The nature of relationship between the two in Islamic deposits and investment accounts is dependent on the underlying contracts employed by them for instance, qard (loan) wadiah (trust), wadiah yad dhamanah (trust with liability), mudharabah (partnership), wakalah (agency) or tawarruq (sale). Since garnishee proceeding is only viable for a debt-based contract which establishes debtorcreditor relationship, is it now possible to apply it to all types of Islamic deposits and investment accounts placed at the IFIs? 


\section{What is garnishee proceeding?}

Garnishee proceeding is common in Malaysia as one of the method of enforcement of judgment obtained from the court (Mei Pheng \& Samen, 2006). It is also usual to execute a garnishee proceeding on bankers conventionally should the judgment debtor has placed certain amount of money in his account provided by his bank. Once it is served on the relevant bank, the court will order the bank to pay to the judgment creditor to satisfy the judgment amount owed by his customer judgment debtor since the bank is the debtor to its customers.

The procedure for the enforcement of judgment via a garnishee proceeding is laid down in Order 49 of the Rules of Court 2012. The mentioned Order 49 allows the judgment creditor who has obtained a judgment or an order for the payment of money by the judgment debtor to apply to the court for the payment of the judgment sum or the sum mentioned in the order for payment from a person who is indebted to the judgment debtor (a garnishee). The court may order the garnishee to pay the judgment creditor the amount of any debt due or accruing due to the judgment debtor from the garnishee or so much as it is sufficient to satisfy that judgment or order and the costs of the garnishee proceedings. It is clearly mentioned in Rule 1(3) of the same Order 49 that the amount of debt due or accruing due includes a current or deposit account with a bank or other financial institution, whether or not the deposit has matured or any restriction as to the mode of withdrawal has been made or otherwise.

\section{Islamic deposits and investment accounts under the purview of the Islamic Financial Services Act 2013}

Since riba and interest are prohibited in Islam, IFIs all over the world have employed various types of underlying contracts for the products they offer on the deposit accounts. Undeniably, Islamic deposit and investment accounts are contracted based on the different aqad (underlying contracts) which eventually implicate distinguished features from a contract to one another. For instance, Qard is a contract of loan, hence the Shariah principles governing loan will be applicable to the contract. Wadiah contract on the other hand is based on trust, the principles of Islamic trust are applicable. If the account is contracted based on Wadiah Yad Dhamanah, the principle of Qard will apply on the account since it is a trust with liability contract as ruled by the Shariah Advisory Council (SAC) of Bank Negara Malaysia (BNM) in its $6^{\text {th }}$ special meeting dated 8 May 2008.

In Malaysia, the newly enacted Islamic Financial Services Act (IFSA) 2013 has paved a new way in defining Islamic deposit. The IFSA 2013 clearly demarcated 'Islamic deposit' and 'investment account'. Section 2 of IFSA 2013 defines 'Islamic deposit' as the money required, among others, to be paid 
and accepted by the bank on terms that it will be repaid in full, whereas, the 'investment account' is the money that is required to be paid and accepted by the bank for the purposes of investment without any express or implied indication as to the obligation to repay the money in full (Abdul Rahman \& Abdullah, 2015). This segregation of definitions was not found in the previous governing law, namely Islamic Banking Act (IBA) 1983 since investment account was made part of the definition of Islamic deposits as appeared in Section 2 of the repealed Act.

Based on the definitions made by IFSA 2013, Islamic deposit is now limited to the money deposited in the saving or current accounts which could only be based on the principle of Qard, Wadiah or Wadiah Yad Dhamanah. The investment account on the other hand appears to be limited solely to investment thereby implying the restricted application of Shariah underlying contracts to Mudharabah, Musharakah, Tawarruq and Wakalah Bi Al-Istithmar only. As far as the Islamic deposit is concerned, whether or not it is current or saving account, the only accounts that could be exposed to the garnishee proceeding are those based on Qard and Wadiah Yad Dhamanah since both underlying contracts establish debtor-creditor relationship. This position implies that any Wadiahbased account could not be made vulnerable to this proceeding since the nature of its contract is trust. Undoubtedly, the Islamic investment account may not be subjected to any garnishee proceeding since the debt obligation does not arise between the IFIs and their customers.

Indeed, the key factor in deciding whether the accounts maintained at an IFI may be garnished or not is whether the relationship between the IFI and its customer is a relationship of debtor and creditor or not (Abdul Rahman \& Abdullah, 2015). This is a crucial point to see whether there is a debt due or accruing due by the IF to the customer or otherwise. In deciding so, it is pertinent to closely examine the nature of each of the Shariah contracts employed as the basis of the contracts made between the contracting parties.

\section{Conclusion}

Thus, it may be concluded that the garnishee proceeding is suitable for the execution of the judgment obtained by a judgment creditor against a conventional bank garnishee on all types of its deposit accounts but not necessarily so on the Islamic deposit accounts and its investment accounts placed at an IFI. This is because the conventional banking deposits placed by a customer at his conventional bank result in a debtor-creditor relationship. It is settled that under the Islamic law of transactions, the nature, rights and liability of the contracting parties of any Shariah contract are determined by the type of contract employed. Since a garnishee proceeding could only be brought against a debtor-creditor 
based account, therefore it is only applicable to Qard-based and Wadiah Yad Dhamanah-based deposit account. The proceeding could not be possibly initiated on a Wadiah-based account any Islamic investment account since the debtorcreditor relationship does not exist in the contract involved. This position indeed restricts the application of garnishee proceeding on the Islamic banking accounts since it is only applicable to selected deposit accounts. Therefore, Islamic banking accounts would be perceived as less favourable by the judgment creditor compared to the conventional banking accounts. In other words the position suggests that in debt recovery action via garnishee proceeding, the judgment creditor has more options in garnishing conventional deposit account rather than Islamic deposits and investment accounts. This means that the judgment creditor must proceed with other types of recovery methods when he finds that the account of the judgment debtor with garnishee is not a debt-based account.

\section{Notes}

* Apnizan Abdullah is Research Fellow at IAIS Malaysia (Email: apnizan@iais. org.my).

\section{References}

1. Abdul Rahman, Abdullah and Abdullah, Apnizan. (June, 2015). Key Consideration in making Third Party Debt Order for an Islamic Banking Account: An Overview of the Positions in England and Malaysia. Islamic Finance News, pp.23-24.

2. Bank Negara Malaysia, (2010). Shariah Resolutions for Islamic Finance. Kuala Lumpur: BNM

3. International Shariah Research Academy for Islamic Finance, (2012). Islamic Financial System Principles and Operations. Kuala Lumpur: Pearson Custom Publishing.

4. Mei Pheng, Lee and Samen, Detta (2006). Banking Law. Kelana Jaya: Lexis Nexis.

\section{List of Statutes}

1. Rules of Court 2012

2. Islamic Financial Services Act 2013

3. Islamic Banking Act 1983 